\title{
Correlation of clinical and deletion data in Duchenne and Becker muscular dystrophy
}

\author{
SHIRLEY HODGSON* , KEVIN HART*§, STEPHEN ABBS*, \\ JOHN HECKMATT $\dagger$, ELIANA RODILLO $\dagger$, MARTIN BOBROW*, AND \\ VICTOR DUBOWITZ† \\ From * the Paediatric Research Unit, Division of Medical and Molecular Genetics, United Medical and Dental \\ Schools, Guy's Hospital, London SE1 9RT; and tDepartment of Paediatrics and Neonatal Medicine, \\ Hammersmith Hospital, Du Cane Road, London W12 OHS.
}

SUMmARY Cloned cDNA sequences representing exons from the Duchenne/Becker muscular dystrophy (DMD/BMD) gene were used for deletion screening in a population of 287 males affected with DMD or BMD. The clinical phenotypes of affected boys were classified into three clinical severity groups based on the age at which ambulation was lost. Boys in group 1 had DMD, losing ambulation before their 13th birthday; those in group 2 had disease of intermediate severity, losing ambulation between the ages of 13 and 16 years; and boys in group 3 had BMD, being ambulant beyond 16 years. A fourth group consisted of patients too young to be classified. Clinical group allocation was made without previous knowledge of the DNA results.

A gene deletion was found in 124 cases where the clinical severity group of the affected boy was known. The extent of the deletions was delineated using cDNA probes. There were 74 different deletions. Fifty-five of these were unique to individual patients, but the other 19 were found in at least two unrelated patients.

The different clinical groups showed generally similar distributions of deletions, and the number of exon bands deleted (that is, deletion size) was independent of phenotype. Some specific deletion types, however, correlated with the clinical severity of the disease. Deletion of exons containing HindIII fragments 33 and 34 and 33 to 35 were associated with BMD and were not found in patients with DMD. Deletions 3 to 7 occurred in four patients with the intermediate phenotype and one patient with BMD. Other shared deletions were associated with DMD, although in four cases patients with disease of intermediate severity apparently shared the same deletion with boys with DMD.

The range of phenotypes observed, and the overlap at the genetic level between severe and intermediate and mild and intermediate forms of dystrophy, emphasises the essential continuity of the clinical spectrum of DMD/BMD.

There were no characteristic deletions found in boys with mental retardation or short stature which differed from deletions in affected boys without these features.

Duchenne muscular dystrophy (DMD) is an $\mathrm{X}$ linked recessive neuromuscular disorder occurring in about one in 3000 males. Affected boys become wheelchair bound by 13 years of age and few live beyond the second decade. Becker muscular dys-

$\ddagger$ Present address: Department of Clinical Genetics, Addenbrooke’s Hospital, Hills Road, Cambridge CB2 2QQ.

§Present address: ICI Diagnostics, Gadbrook Park, Northwich, Cheshire CW9 7RA.

Received for publication 5 May 1989.

Accepted for publication 31 May 1989 trophy (BMD) has a similar distribution of muscle weakness, but the course of the disease is slower and milder: ambulation is retained beyond 16 years and affected males may have a normal life span. About one third of boys with DMD have some degree of mental retardation, ${ }^{12}$ whereas intelligence in BMD is usually normal. ${ }^{3}$ There are also affected boys whose clinical course is intermediate between BMD and classical DMD, who become unable to walk between 13 and 16 years of age. 
The DMD and BMD loci are allelic and have been localised within Xp21.45 The genomic sequences pERT87 ${ }^{6}$ and pXJ1.1 ${ }^{7}$ were found to detect submicroscopic deletions, by non-hybridisation of patient DNA to these sequences, in a proportion of patients with both DMD and BMD. 89

cDNAs representing exons of the $\mathrm{DMD} / \mathrm{BMD}$ gene (which codes for a $14 \mathrm{~kb} \mathrm{mRNA}^{10-14}$ ) have been used to screen for exon deletions in affected males, and have shown deletions in over half the cases of DMD and BMD. ${ }^{12} 1315$

The size of the deletion is not simply correlated with the severity of disease. ${ }^{16} 17$ It has been postulated that some exon deletions cause DMD while others cause the milder BMD, because deletions causing DMD shift the translational open reading frame, resulting in a severely truncated protein gene product, whereas in BMD the translational reading frame may be maintained in phase, resulting in an abnormal, but partially functional, protein product. ${ }^{17-19}$ This would be compatible with the observation that cases of BMD often have an abnormal size of dystrophin, whereas DMD patients almost invariably have no demonstrable dystrophin. ${ }^{20}$

Exon deletions, both at the $5^{\prime}$ and in the central region of the gene, have been described which appear specifically to be associated with a milder phenotype. ${ }^{1921} \mathrm{~A}^{\prime}$ deletion (of exons 3 to 7) has been found in six BMD, five intermediate, and two DMD patients. ${ }^{21}$ It is predicted that this deletion disrupts the translational reading frame. These mild phenotypes may be the result of differential splicing, an alternative in frame translation start site, or a second promoter site, which could compensate for the effects of this frameshift mutation.

Since dystrophin may be expressed in neurones, ${ }^{22} 23$ it may be important for normal neuronal development or function, and variable mental retardation may be an inherent effect of the DMD mutation. ${ }^{124}$ We set out to correlate phenotypic characteristics of affected males with the position and extent of exon deletions detected using cDNA probes.

\section{Patients}

A total of 287 patients with DMD or BMD was ascertained from the Paediatric Muscle Clinic at the Hammersmith Hospital, and from the South-East Thames Regional Genetics Centre, Guy's Hospital, London. Clinical details were obtained personally or from the hospital records, and in a few cases by contacting the referring physician. In all cases the diagnosis was confirmed by the finding of markedly raised serum creatine kinase (CK) levels and characteristic muscle biopsy findings. ${ }^{24}$ Information about developmental milestones, school performance, and height centiles was obtained from the clinical records, and was available for most cases ascertained through the Hammersmith and Guy's Hospital clinics. Physiotherapists' records were used to assess clinical severity in cases who had not yet lost ambulation at the time of study. In most cases no formal assessment of intelligence was possible; IQ tests had been performed on a few cases attending the Muscle Clinic at Hammersmith Hospital. In other cases an estimate of intelligence was made from the school performance record. Where the affected boy was attending a school for the educationally subnormal, this was taken to indicate educational subnormality (ESN).

Cases were divided into groups according to the age at which ambulation was lost, or the age reached without loss of ambulation. Most Duchenne cases had undergone Achilles tenotomies and the fitting of lightweight orthoses (calipers) when they were unable to walk any distance but could still stand alone and take a few steps. For the purposes of this survey this was used to indicate the age at which ambulation was lost. ${ }^{25}$ In three cases who were still ambulant between $11 \frac{1 / 2}{2}$ and 12 years at the time of study (cases 46036, 46167, and 45049), the clinical impression was that they would lose ambulation between 13 and 16 years; these boys were therefore included in the group of intermediate severity. Cases 42403 and 45987, ambulant at 15 years of age, had only mild disability and were included in the BMD group (3). Cases were classified into the following groups.

Group 1: $D M D$ where ambulation was lost before the 13th birthday. This group was subdivided into: (a) more severe DMD: ambulation lost before the age of 10 years. There were 37 boys in this group ( $29.8 \%$ of the total); (b) less severe DMD: ambulation lost between 10 years and 12 years 11 months of age. There were 30 boys in this group $(24 \cdot 2 \%)$.

Group 2: intermediate severity where ambulation was lost (or, in three cases, expected to be lost) between 13 years and 15 years 11 months of age. There were 12 boys in this group $(9.7 \%)$.

Group 3: $B M D$ where ambulation was maintained beyond 16 years of age (13 boys) $(10 \cdot 5 \%)$. Case 44230 lost ambulation at 16 years five months. All other boys in group 3 were still ambulant at 16 years of age or over (including cases 42403 and 45987 , referred to above) and had mild disability on clinical assessment. 
TABLE 1 Proportions of clinical parameters found in each clinical severity group.

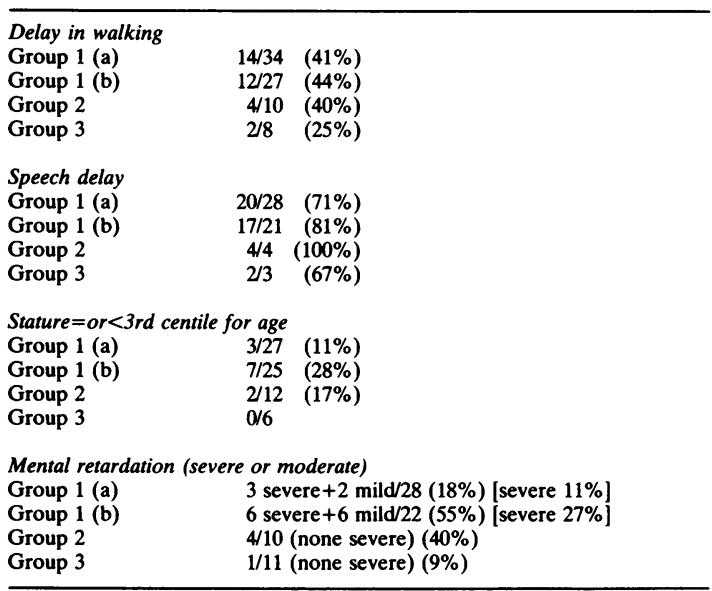

TABLE 2 Clinical details of boys in each group. GROUP 1: DMD

Group 1 (a): lost ambulation before 10 years of age.

\begin{tabular}{|c|c|c|c|c|c|}
\hline No & $\begin{array}{l}\text { First } \\
\text { walked } \\
\text { (mth) }\end{array}$ & $\begin{array}{l}\text { First } \\
\text { sentences }\end{array}$ & $\begin{array}{l}\text { Height } \\
\text { (centile) }\end{array}$ & $\begin{array}{l}\text { Age ceased } \\
\text { to walk }\end{array}$ & $I Q$ \\
\hline 33202 & 16 & $3 y$ & 10 & 8 y $6 \mathrm{mth}$ & SL $R$ \\
\hline 46364 & 14 & $2 y$ & 10 & $9 y$ & ESN (M) \\
\hline 33172 & 16 & & 50 & 8 y $6 \mathrm{mth}$ & \\
\hline 46878 & 18 & Late & 10 & 8 y $6 \mathrm{mth}$ & $\mathbf{N}$ \\
\hline 41622 & 24 & & & $7 y$ & $\mathrm{~N}$ \\
\hline 43052 & $12-14$ & & 25 & $9 y$ & $\mathrm{~N}$ \\
\hline 45061 & 13 & $18 \mathrm{mth}$ & 3 & 9 y $6 \mathrm{mth}$ & \\
\hline 43053 & 24 & 3 y $6 \mathrm{mth}$ & 75 & 6 y $6 \mathrm{mth}$ & \\
\hline 46162 & 15 & $2 y$ & 25 & 8 y $6 \mathrm{mth}$ & $\mathbf{N}$ \\
\hline 40106 & 18 & 2 y $6 \mathrm{mth}$ & 25 & 7 y $2 \mathrm{mth}$ & $\mathbf{R}$ \\
\hline 33189 & 26 & $3 y$ & 25 & 9 y 6 mth & $\mathbf{R}$ \\
\hline 33196 & 17 & $15 \mathrm{mth}$ & $<3$ & 9 y $4 \mathrm{mth}$ & $\mathbf{N}$ \\
\hline 48439 & & & & $7 y$ & \\
\hline 44416 & 19 & 2 y $6 \mathrm{mth}$ & 25 & 8 y $6 \mathrm{mth}$ & $\mathbf{N}$ \\
\hline 33180 & 30 & $>2 y$ & 25 & $8 y$ & \\
\hline 33169 & 21 & $2 y$ & & $8 y$ & $\mathrm{~N}$ \\
\hline 42915 & 16 & & 10 & $8 y$ & $\mathrm{~N}$ \\
\hline 44979 & 20 & $15 \mathrm{mth}$ & & $9 \mathrm{y}$ & $\mathrm{N}$ \\
\hline 46958 & 13 & & 75 & $9 \mathrm{y}$ & $\mathbf{N}$ \\
\hline 42203 & 18 & $2 y$ & 10 & $7 y$ & $\mathrm{~N}$ \\
\hline 38777 & 12 & Early & & 6 y $9 \mathrm{mth}$ & \\
\hline 44765 & 11 & $18 \mathrm{mth}$ & 50 & $9 \mathrm{y}$ & \\
\hline 46038 & 17 & $2 y$ & 50 & $8 y$ & $\mathrm{~N}$ \\
\hline 33374 & 24 & & 25 & $9 \mathrm{y}$ & $\mathbf{N}$ \\
\hline 44966 & & & & $9 \mathrm{y}$ & $\mathbf{N}$ \\
\hline 45263 & 12 & 2 y $6 \mathrm{mth}$ & & 8 y $1 \mathrm{mth}$ & \\
\hline 41165 & 14 & 2 y $6 \mathrm{mth}$ & 25 & $9 y$ & $\mathbf{N}$ \\
\hline 13011 & 13 & $2 y$ & & $8 \mathrm{y}$ & $\mathrm{N}$ \\
\hline 42915 & 24 & $2 y$ & $<3$ & $8 y$ & \\
\hline 48698 & $\mathrm{~N}$ & & & $9 \mathrm{y}$ & $\mathbf{N}$ \\
\hline 44988 & 21 & $3 y$ & 50 & 8 y $3 \mathrm{mth}$ & \\
\hline 45976 & 19 & $18 \mathrm{mth}$ & 50 & 8 y $9 \mathrm{mth}$ & $\mathrm{N}$ \\
\hline 35706 & 15 & & 25 & 9 y $3 \mathrm{mth}$ & $\mathrm{N}$ \\
\hline 44601 & $12-18$ & Late & & 8 y $11 \mathrm{mth}$ & $\mathrm{N}$ \\
\hline 33190 & 15 & & 25 & 8 y $6 \mathrm{mth}$ & IQ 84 \\
\hline 45056 & & $21 \mathrm{mth}$ & 50 & 9 y $8 \mathrm{mth}$ & $\mathrm{N}$ \\
\hline 33197 & 14 & $2 y$ & 25 & $9 y$ & $\mathbf{N}$ \\
\hline
\end{tabular}

Delay in talking $>2$ y: 20/28. Delay in walking $>17 \mathrm{mth}: 14 / 34$ Stature at or below 3rd centile: $3 / 27$. Mentally retarded: $5 / 28$ ( 3 severe).
Group 1 (b): lost ambulation between 10 years and 12 years 11 months of age.

\begin{tabular}{|c|c|c|c|c|c|}
\hline No & $\begin{array}{l}\text { First } \\
\text { walked } \\
\text { (mth) }\end{array}$ & $\begin{array}{l}\text { First } \\
\text { sentences }\end{array}$ & $\begin{array}{l}\text { Height } \\
\text { (centile) }\end{array}$ & $\begin{array}{l}\text { Age ceased } \\
\text { to walk }\end{array}$ & $I Q$ \\
\hline 41790 & 42 & $2 y$ & & $12 \mathrm{y}$ & $\mathrm{N}$ \\
\hline 33211 & 48 & 2 y $6 \mathrm{mth}$ & 50 & $12 y$ & $\operatorname{ESN}(M)$ \\
\hline 33175 & 24 & 4 y $6 \mathrm{mth}$ & 50 & $10 \mathrm{y}$ & $\mathbf{R}$ \\
\hline 32936 & 15 & 1 y $6 \mathrm{mth}$ & $<3$ & $11 \mathrm{y}$ & \\
\hline 17748 & 18 & $2 y$ & 50 & 10 y $9 \mathrm{mth}$ & IQ 87 \\
\hline 33187 & 14 & 3 y $6 \mathrm{mth}$ & 50 & $11 \mathrm{y}$ & $\operatorname{ESN}(M)$ \\
\hline 45527 & 18 & & $<3$ & $10 \mathrm{y}$ & SL $R$ \\
\hline 33217 & 18 & & 50 & 11 y $6 \mathrm{mth}$ & \\
\hline 45070 & 15 & & & 10 y 9 mth & \\
\hline 37965 & 18 & $2 y$ & 97 & 11 y 6 mth & $\mathbf{N}$ \\
\hline 48462 & & & $<3$ & 10 y $6 \mathrm{mth}$ & \\
\hline 46020 & 17 & $18 \mathrm{mth}$ & & $10 \mathrm{y}$ & \\
\hline 41443 & 17 & $18 \mathrm{mth}$ & $<3$ & $12 y$ & $\mathrm{~N}$ \\
\hline 42706 & 24 & 4 y $6 \mathrm{mth}$ & 3 & $10 \mathrm{y}$ & \\
\hline 33216 & 12 & & $<3$ & $10 \mathrm{y}$ & SL R \\
\hline 33205 & 15 & $3 y$ & 10 & 11 y $6 \mathrm{mth}$ & $\mathrm{N}$ \\
\hline 42512 & 24 & $3 y$ & 10 & $12 \mathrm{y}$ & SL R \\
\hline 53176 & & & 25 & $10 \mathrm{y}$ & \\
\hline 20832 & 15 & 3 y $6 \mathrm{mth}$ & 10 & 11 y $6 \mathrm{mth}$ & IQ 85 \\
\hline 44189 & 24 & $5 \mathrm{y}$ & 10 & $12 y$ & 1071 \\
\hline 45637 & & & & $12 y$ & \\
\hline 20708 & 17 & Delayed & 10 & $10 \mathrm{y}$ & $\mathrm{N}$ \\
\hline 43111 & 14 & & $3-10$ & $12 \mathrm{y}$ & ESN \\
\hline 42513 & 12 & & $<3$ & $10 \mathrm{y}$ & $\mathrm{N}$ \\
\hline 46018 & 27 & Delayed & 10 & 10 y $6 \mathrm{mth}$ & $\mathrm{N}$ \\
\hline 42018 & 15 & $3 y$ & 25 & $10 \mathrm{y}$ & ESN \\
\hline 16861 & 18 & 2 y $6 \mathrm{mth}$ & & $12 \mathrm{y}$ & ESN (M) \\
\hline 44987 & 15 & $2 y$ & 50 & 10 y $3 \mathrm{mth}$ & IO 112 \\
\hline 45515 & 15 & 2 y $6 \mathrm{mth}$ & 25 & 11 y 6 mth & $\mathrm{N}$ \\
\hline 34517 & 15 & Early & 90 & 12 y $9 \mathrm{mth}$ & $\mathrm{N}$ \\
\hline
\end{tabular}

Delay in talking $>2 \mathrm{y}: 17 / 21 . \quad$ Delay in walking $>17 \mathrm{mth}: 12 / 27$. Stature at or below 3rd centile: $7 / 25$. Mentally retarded: $12 / 22$ (6 severe).

GROUP 2: INTERMEDIATE

Group 2: lost ambulation between 13 and 16 years of age.

\begin{tabular}{|c|c|c|c|c|c|}
\hline No & $\begin{array}{l}\text { First } \\
\text { walked } \\
\text { (mth) }\end{array}$ & $\begin{array}{l}\text { First } \\
\text { sentences }\end{array}$ & $\begin{array}{l}\text { Height } \\
\text { (centile) }\end{array}$ & $\begin{array}{l}\text { Age ceased } \\
\text { to walk }\end{array}$ & $I Q$ \\
\hline 46036 & 14 & & 50 & & SL R \\
\hline 46167 & 14 & & 25 & & \\
\hline 46405 & 22 & $3 y$ & 25 & $14 y$ & SL R \\
\hline 08630 & 24 & & 90 & $15 y$ & $\mathbf{N}$ \\
\hline 42786 & 14 & & 25 & 14 y $6 \mathrm{mth}$ & SL R \\
\hline 33193 & 13 & $2 y$ & 10 & $13 y$ & $\mathbf{N}$ \\
\hline 33212 & 22 & & 25 & $13 y$ & $\mathbf{N}$ \\
\hline 33174 & & 3 y $6 \mathrm{mth}$ & 3 & $13 y$ & $\mathbf{N}$ \\
\hline 41688 & 22 & & 10 & $13 y$ & $\mathbf{N}$ \\
\hline 46034 & 16 & $4 y$ & 75 & $13 y$ & SL R \\
\hline 45049 & 12 & & 3 & & $\mathbf{N}$ \\
\hline 33381 & & & 10 & 13 y $4 \mathrm{mth}$ & \\
\hline
\end{tabular}

Delay in talking $>2$ y: $4 / 4 . \quad$ Delay in walking $>17 \mathrm{mth}: 4 / 10$ Stature at or below 3rd centile: $2 / 12$. Mentally retarded: $4 / 10(0$ severe $)$. 
GROUP 3: BMD

Group 3: still walking after 16 years of age.

\begin{tabular}{|c|c|c|c|c|c|}
\hline No & $\begin{array}{l}\text { First } \\
\text { walked } \\
\text { (mth) }\end{array}$ & $\begin{array}{l}\text { First } \\
\text { sentences }\end{array}$ & $\begin{array}{l}\text { Height } \\
\text { (centile) }\end{array}$ & $\begin{array}{l}\text { Age at } \\
\text { investigation }\end{array}$ & $I Q$ \\
\hline 44230 & 21 & $3 y$ & 10 & 16 y $6 \mathrm{mth}^{*}$ & $\mathbf{N}$ \\
\hline 45002 & 14 & & 50 & $18 \mathrm{y}$ & $\mathbf{N}$ \\
\hline 44434 & & & & $18 \mathrm{y}$ & \\
\hline 33213 & 18 & & 50 & 18 y $10 \mathrm{mth}$ & $\mathbf{N}$ \\
\hline 38604 & 16 & & & $18 y$ & $\mathbf{N}$ \\
\hline 42403 & 14 & & 97 & $15 \mathrm{yt}$ & $\mathrm{N}$ \\
\hline 46115 & & & & 17 y $4 \mathrm{mth}$ & \\
\hline 45987 & Normal & & & $15 \mathrm{yt}^{t}$ & SL $\mathbf{R}$ \\
\hline 39744 & & & & $40 y$ & $\mathbf{N}$ \\
\hline 45996 & 14 & $2 \mathrm{y} \mathrm{mth}$ & 10 & $23 y$ & $\mathbf{N}$ \\
\hline 43848 & & & & $33 y$ & $\mathbf{N}$ \\
\hline 43055 & 14 & Normal & 10 & $20 \mathrm{y}$ & $\mathbf{N}$ \\
\hline 32060 & & & & $25 y$ & \\
\hline
\end{tabular}

Delay in talking $>2$ y: $2 / 3$. Delay in walking $>17 \mathrm{mth}: 2 / 8$.

Stature at or below 3rd centile: $0 / 6$. Mentally retarded: $1 / 11$ (0 severe).

*Just off feet. +Still walking well at $15 \mathrm{y}$; expected to maintain ambulation beyond $16 \mathrm{y}$.

Group 4: less than 10 years at time of study; still ambulant.

\begin{tabular}{|c|c|c|c|c|c|c|}
\hline No & $\begin{array}{l}\text { First } \\
\text { walked } \\
(m t h)\end{array}$ & $\begin{array}{l}\text { First } \\
\text { sentences }\end{array}$ & $\begin{array}{l}\text { Height } \\
\text { (centile) }\end{array}$ & $\begin{array}{l}\text { Estimated } \\
\text { group }\end{array}$ & $I Q$ & Age \\
\hline 43991 & & & & 1 & $\mathbf{N}$ & $6 y$ \\
\hline 44047 & 17 & Normal & & & $\mathbf{N}$ & $8 y$ \\
\hline 46535 & 12 & $2 y$ & 50 & & $\mathbf{N}$ & 3 y $6 \mathrm{mth}$ \\
\hline 18402 & 12 & 2 y $6 \mathrm{mth}$ & 25 & 2 & $\mathbf{N}$ & 7 y $6 \mathrm{mth}$ \\
\hline 41821 & 21 & 2 y $6 \mathrm{mth}$ & 25 & & $\mathbf{N}$ & 8 y $6 \mathrm{mth}$ \\
\hline 44268 & 14 & & & 1 & $\mathbf{N}$ & $6 y$ \\
\hline 45050 & 15 & $20 \mathrm{mth}$ & 3 & & $\mathbf{N}$ & $3 y$ \\
\hline 40203 & 18 & 2 y $6 \mathrm{mth}$ & 3 & & & $8 y$ \\
\hline 39487 & 13 & $18 \mathrm{mth}$ & 25 & & & $8 y$ \\
\hline 43484 & 12 & & & 1 & & 5 y $6 \mathrm{mth}$ \\
\hline 45436 & 17 & $14 \mathrm{mth}$ & 10 & 1 & SL $R$ & $9 y$ \\
\hline 42657 & 20 & & & & & $6 y$ \\
\hline 42583 & 12 & $20 \mathrm{mth}$ & 25 & & & 6 y $6 \mathrm{mth}$ \\
\hline 42021 & 12 & Late & 10 & 1 & $\mathbf{N}$ & $7 y$ \\
\hline 48942 & 18 & & 50 & & & $4 y$ \\
\hline 43485 & & & & 1 & $\mathrm{~N}$ & $7 y$ \\
\hline 44247 & 12 & $2 y$ & 50 & & $\mathbf{N}$ & $6 y$ \\
\hline 42095 & 23 & $3 y$ & 25 & 1 & $\mathbf{N}$ & $8 y$ \\
\hline 40335 & 18 & $15 \mathrm{mth}$ & 25 & 1 & & $6 y$ \\
\hline 41832 & 13 & $18 \mathrm{mth}$ & & & & $6 y$ \\
\hline 36504 & 18 & Normal & & 1 & $\mathbf{N}$ & $6 y$ \\
\hline 40329 & 18 & $18 \mathrm{mth}$ & & & $\mathbf{R}$ & $7 y$ \\
\hline 12376 & $\begin{array}{l}\text { Affectec } \\
\text { ambulat }\end{array}$ & $\begin{array}{l}\text { grandfather } \\
\text { ion in } 40 \mathrm{~s}\end{array}$ & lost & 3 & & $5 y$ \\
\hline 37229 & & & 3 & 1 & $\mathrm{~N}$ & $9 y$ \\
\hline 40784 & 19 & 2 y $6 \mathrm{mth}$ & & & & $5 y$ \\
\hline 45480 & 14 & $3 y$ & 10 & 3 & $\mathbf{R}$ & 7 y $6 \mathrm{mth}$ \\
\hline 45036 & 15 & $>18 \mathrm{mth}$ & 10 & & SL $R$ & 3 y $6 \mathrm{mth}$ \\
\hline 37797 & 20 & 3 y $6 \mathrm{mth}$ & $3-10$ & & & $6 y$ \\
\hline 49951 & 14 & $2 y$ & 25 & & $\mathbf{N}$ & $5 y$ \\
\hline 42582 & 18 & Slow & 50 & & & 5 y $6 \mathrm{mth}$ \\
\hline 46751 & 13 & $18 \mathrm{mth}$ & $<3$ & 3 & $\mathbf{N}$ & $9 y$ \\
\hline 46116 & 24 & $2 \mathrm{y}$ & & 1 & & 8 y $6 \mathrm{mth}$ \\
\hline
\end{tabular}

Delay in talking $>2 \mathrm{y}: 12 / 24$

Delay in walking $>17 \mathrm{mth}: 12 / 29$ Stature at or below 3rd centile: $4 / 20$. $\mathrm{ESN}=$ educationally subnormal. Mentally retarded: $4 / 19$ ( 2 severe $)$ $\mathrm{N}=$ normal. $S L R=$ slight mental retardation. Height given as centile of height for age

Hind III band fragments detected by cDNA probes used in this study. Exon fragments are numbered 1 to 64 . ordered on data from Koenig et al. . $^{13}$ Malhotra et al, ${ }^{21}$ Burghes $e t a l,,^{30}$ and Wapenaar et al. ${ }^{31}$ Sizes of HindiII fragments are in kilobases. The order of the bracketed exon fragments is not known. Band 58 was not evident on our autoradiograms.

*This exon fragment is not numbered as it forms part of the next $10 \mathrm{~kb}$ exon fragment, but is split by a HindIII site in the cDNA. The exact position of other split exons is not known.
TABLE 3 Numbers assigned to HindIII exon bands.

\begin{tabular}{|c|c|c|}
\hline Exon band & & No \\
\hline \multicolumn{3}{|l|}{$5^{\prime}$} \\
\hline \multirow[t]{2}{*}{$9-7$} & $3 \cdot 2$ & 1 \\
\hline & $3 \cdot 2$ & 2 \\
\hline \multirow{6}{*}{$\mathrm{XJcDNAl} \rightarrow$} & $\begin{array}{l}4 \cdot 2 \\
8 \cdot 5\end{array}$ & $\begin{array}{l}3 \\
4\end{array}$ \\
\hline & $3 \cdot 1$ & 5 \\
\hline & 8.0 & 6 \\
\hline & $4 \cdot 6$ & 7 \\
\hline & $7 \cdot 5$ & 8 \\
\hline & $10 \cdot 5$ & 9 \\
\hline \multirow[t]{7}{*}{30.2} & $4 \cdot 2$ & 10 \\
\hline & 6.6 & 11 \\
\hline & 2.7 & 12 \\
\hline & $6 \cdot 0$ & 13 \\
\hline & 1.7 & 14 \\
\hline & $12 \cdot 0$ & 15 \\
\hline & $3 \cdot 0$ & 16 \\
\hline \multirow{5}{*}{30.1} & $7 \cdot 3$ & 17 \\
\hline & $11 \cdot 0$ & 18 \\
\hline & $20 \cdot 0$ & 19 \\
\hline & $\begin{array}{r}5.2 \\
12.0\end{array}$ & 20 \\
\hline & $\begin{array}{r}12.0 \\
4 \cdot 7\end{array}$ & 22 \\
\hline \multirow[t]{6}{*}{47.4} & 18.0 & 23 \\
\hline & 0.45 & 24 \\
\hline & $1 \cdot 3$ & 25 \\
\hline & $1.8\}$ & 26 \\
\hline & $\begin{array}{l}1.5 \\
6.0\end{array}$ & $\begin{array}{l}27 \\
28\end{array}$ \\
\hline & $6 \cdot 2$ & 29 \\
\hline \multirow[t]{5}{*}{ CF23a $\rightarrow$} & $11.0\}$ & 30 \\
\hline & $4 \cdot 2\}$ & 31 \\
\hline & $4 \cdot 1$ & 32 \\
\hline & 0.5 & 33 \\
\hline & $1 \cdot 5^{*}$ & \\
\hline \multirow[t]{6}{*}{44.1} & $10 \cdot 0$ & 34 \\
\hline & 1.25 & 35 \\
\hline & $3 \cdot 8$ & 36 \\
\hline & $\begin{array}{l}1.6 \\
3.7\end{array}$ & $\begin{array}{l}37 \\
38\end{array}$ \\
\hline & $3 \cdot 1$ & 39 \\
\hline & $7 \cdot 0$ & 40 \\
\hline \multirow[t]{5}{*}{$63.1(9)$} & $7.8\}$ & 41 \\
\hline & $8.3\}$ & 42 \\
\hline & $1 \cdot 0$ & 43 \\
\hline & $\begin{array}{l}2.3 \\
1.0\end{array}$ & $\begin{array}{l}44 \\
45\end{array}$ \\
\hline & $\left.\begin{array}{l}1.0 \\
8.8\end{array}\right\}$ & 46 \\
\hline \multirow[t]{6}{*}{$63.1(10)$} & $6 \cdot 0$ & 47 \\
\hline & 3.5 & 48 \\
\hline & 2.6 & 49 \\
\hline & $2 \cdot 8$ & 50 \\
\hline & $\begin{array}{r}6 \cdot 6 \\
12.0\end{array}$ & $\begin{array}{l}51 \\
52\end{array}$ \\
\hline & 2.4 & 53 \\
\hline \multirow[t]{10}{*}{$63.1(11-14)$} & 1.45 & 54 \\
\hline & 1.5 & 55 \\
\hline & 1.9 & 56 \\
\hline & $\begin{array}{l}2 \cdot 1 \\
5 \cdot 2 ?\end{array}$ & $\begin{array}{l}57 \\
58\end{array}$ \\
\hline & 6.8 & 59 \\
\hline & $10 \cdot 0$ & 60 \\
\hline & 1.8 & 61 \\
\hline & 5.9 & 62 \\
\hline & 7.8 & 63 \\
\hline & $6 \cdot 0$ & 64 \\
\hline $3^{\prime}$ & & \\
\hline
\end{tabular}


Group 4 comprised boys still ambulant but below the age of 10 years at the time of the study. There were 32 boys in this group $(25.8 \%$ of the total). Where assessment of severity could be made, 11 were thought to be in group 1 , one in group 2 , and three in group 3 . This group was, however, analysed separately.

Four clinical parameters were assessed wherever possible.

(1) The age at which the child first walked (based on history from the parents).

(2) The age at which two or three words were first used together to form sentences (based on history from the parents).

(3) The height centile taken in the clinic before ambulation was lost.

(4) The level of intelligence.

When onset of walking was delayed to 18 months of age or beyond, this was categorised as abnormally delayed. Speech delay was defined as the inability to make simple sentences after the age of two years. ${ }^{26}$

Clinical details of probands are shown in tables 1 and 2 .

This study includes only those affected males who were found to have deletions of one or more exons. Clinical data were categorised into severity groups without knowledge of the patient deletion data.
Similarly, deletions were characterised without knowledge of the clinical details.

\section{DNA analysis}

Genomic DNA was made as previously described ${ }^{27}$ or, more recently, using a $340 \mathrm{~A}$ Nucleic Acid Extractor (Applied Biosystems Ltd). DNA restriction endonuclease digestion, agarose gel electrophoresis, and Southern blotting were carried out using standard procedures. ${ }^{28}$ Probe DNA was radioactively labelled using a hexanucleotide primed reaction..$^{29}$ Filters were prehybridised for a minimum of two hours in $3 \times \mathrm{SSC}(20 \times \mathrm{SSC}=3 \mathrm{~mol} / \mathrm{l}$ sodium chloride, $0.3 \mathrm{~mol} / \mathrm{l}$ trisodium citrate), $0.1 \%$ sodium dodecyl sulphate, $100 \mu \mathrm{g} / \mathrm{ml}$ denatured salmon sperm DNA, $2 \times$ Denhardt's solution $(100 \times=2 \%$ Ficoll $400,2 \%$ polyvinyl-pyrrolidone, and $2 \%$ bovine serum albumin (pentax fraction $\mathrm{V}$ )) and $8 \%$ dextran sulphate. Hybridisation was carried out overnight at $65^{\circ} \mathrm{C}$ in the same solution, with addition of denatured radioactive probe. Filters were washed down to $0.2 \times$ SSC, $0.1 \%$ SDS at $65^{\circ} \mathrm{C}$ for 30 minutes each. Autoradiography was carried out at $-70^{\circ} \mathrm{C}$ using intensifying screens.

The complete cloned cDNA from the DMD/BMD gene $^{13}$ was made available as six inserts in Bluescript or Bluescribe plasmid vectors, called 9.7, 30.2, 30.1,
$47-4(5 b, 6 c, 7) / H 3$

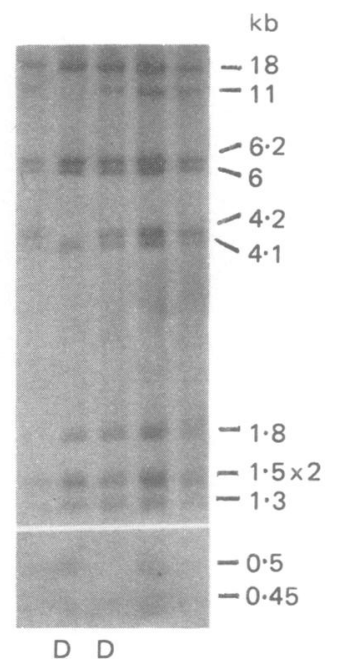

$44-1(8) / \mathrm{H} 3$

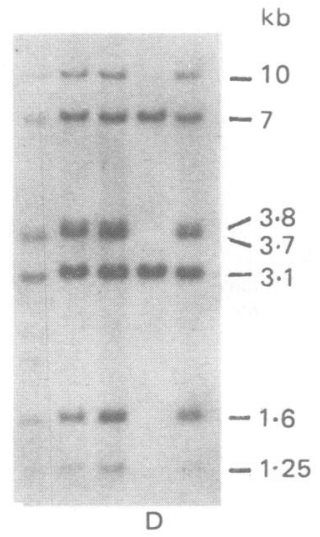

$9 \cdot 7(1,2) / \mathrm{H}^{3}$

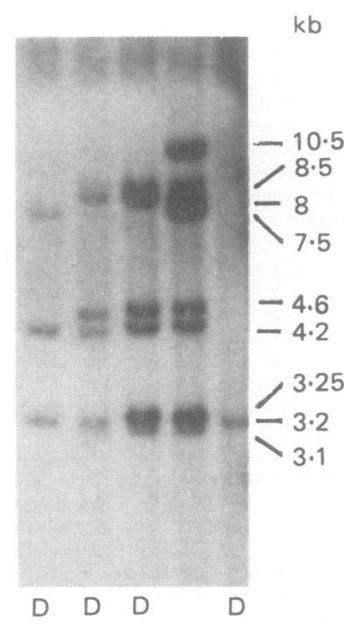

FIG 1 Examples of HindIII restriction endonuclease digestions of genomic DNA from DMD/BMD patients, probed with the cDNA clones 9-7, 47-4, and 44-1. ${ }^{14}$ The normal complement of fragments detected by each probe is shown on the right of each autoradiograph. Sizes are given in kilobases $(k b)$. Lanes showing deletion of one or more fragments are identified by $a$. 
$47.4,44.1$, and 63.1 (in $5^{\prime}$ to $3^{\prime}$ order). They detected 65 Hind III fragments on genomic DNA, with five Hind III sites in the cDNA, thus representing a minimum of 60 exons. The $14 \mathrm{~kb}$ cDNA had been divided into 14 short probes to produce band patterns simple enough to be interpreted. ${ }^{13}$ In this study, purified inserts were used as probes for $9.7,30.2,30.1,47.4$, and 44.1 , corresponding approximately to probes $1+2,2+3,4+5 \mathrm{a}, 5 \mathrm{~b}+6 \mathrm{c}+7$, and 8 , respectively. 63.1 was digested with BamHI to give three smaller inserts that were used as separate probes, namely $63.1 / 9,63.1 / 10$, and $63.1 / 11-14$, corresponding to probes 9,10 , and $11+12+13+14$, respectively. ${ }^{13}$ cDNA clones XJcdna $1^{11}$ and CF23a $\mathrm{a}^{12}$ were also used in this study. XJcdna1 detected the same exon fragments as 9.7 and part of 30.2, while CF23a detected the same exon fragments as the $3^{\prime}$ end of $47.4(6 c+7)$. Exon band ordering was as reported for HindIII fragments. ${ }^{11} 133031$ For simplicity, the exon containing fragments were numbered 1 to 64 from the $5^{\prime}$ end of the gene (table 3).

Genomic deletions ${ }^{32}$ were further mapped by hybridisation against cDNA probes mapping to the deleted loci. Further deletions were detected by routine screening with cDNA probes $44.1,47.4$ or CF23a, and XJcdna1. Remaining undeleted patients were screened with $30.2,30.1,63.1 / 9,63.1 / 10$, and 63.1/11-14 cDNAs. Deletions detected were delineated in full with the requisite cDNAs. ${ }^{33}$

\section{Results}

A total of 163 of the 287 patients initially screened was found to have molecular deletions in the dystrophin gene, and in 142 of these the deletion was delineated with cDNA probes. ${ }^{33}$ In 124 of these patients there was sufficient clinical information to allow clinical severity group allocation. In those families where there were multiple DMD/BMD cases, the disease severity and the deletion were concordant in the different affected males. Only one affected boy per kindred was included in this survey. As far as we are aware, the deletions in this study therefore represent 124 independent mutations.

Deletions were usually defined by the presence or absence of hybridisation signals (fig 1). The solid lines in figs 2 and 3 represent the extents of the deletions. In some cases it was not possible to define the boundary of the deletion clearly (owing to the neighbouring exon fragment giving an equivocal or obscured signal). This is denoted by a question mark in the diagram. In other cases, a junction fragment was indicated by the appearance of an aberrant sized band; this is shown by a ' $\mathrm{J}$ ' in the diagrams (figs 2 and 3). Most deletions were simple linear deletions, but one (46116 in group 4) appeared to be a complex mutation, because of the presence of two abnormally sized bands. ${ }^{33}$ Fig. 2 shows the sites and extents of the deletions found in groups 1 to 4 , indicating those associated with short stature and mental retardation. Fig 3 shows the total range of deletions.

It can be seen that 74 different deletions were identified; 55 were found in only one affected boy, whereas 19 deletions were found in more than one unrelated subject. Table 4 summarises the clinical groups to which the boys found to have common deletions were assigned. The phenotypes were all severe (DMD, group 1) in deletions 32, 33-38, 34, 36-38, 37, and 38. Only mild BMD phenotypes (group 3) were found in deletions 33-34 and 33-35. The intermediate phenotype was predominant in deletion 3-7, but one case had BMD. In each of deletions $8,33,33-36$, and 39 , one case with the intermediate phenotype (group 2) was found in addition to cases of the DMD phenotype.

In nine of the group 4 cases sharing common deletions, where severity could be judged, there was concordance between the assessed severity of group 4 cases and those in groups 1 to 3 found to have the same deletions (see table 4).

There was no obvious difference between the distribution and size of deletions in boys with mental retardation and those of normal intelligence (fig 2 , table 4). Cases with mental retardation were not found to have deletions confined to any one region of the gene, and large deletions occurred both in boys with normal and in those with low intelligence. There was similarly no obvious difference between the distribution and size of deletions found in cases with short stature and those with normal stature.

\section{Discussion}

Within the DMD/BMD spectrum, DMD has been defined by the loss of ambulation by the age of 13 years, whereas ambulation retained beyond the age of 16 years was diagnostic of BMD. ${ }^{3}$ It can be seen from our clinical data that there is no clear dividing line between DMD and BMD, and that $10 \%$ of patients have disease of intermediate severity, where ambulation is lost between 13 and 16 years of age. This concurs with observations from other groups. 3435

Analysis of the deletions (table 4, figs 2 and 3) shows that they are heterogeneous in size and widely distributed within the DMD/BMD gene. There are two regions of the gene prone to deletions, as noted by others. ${ }^{12} 133236$ Where two or more boys have apparently the same deletion, they are of similar 


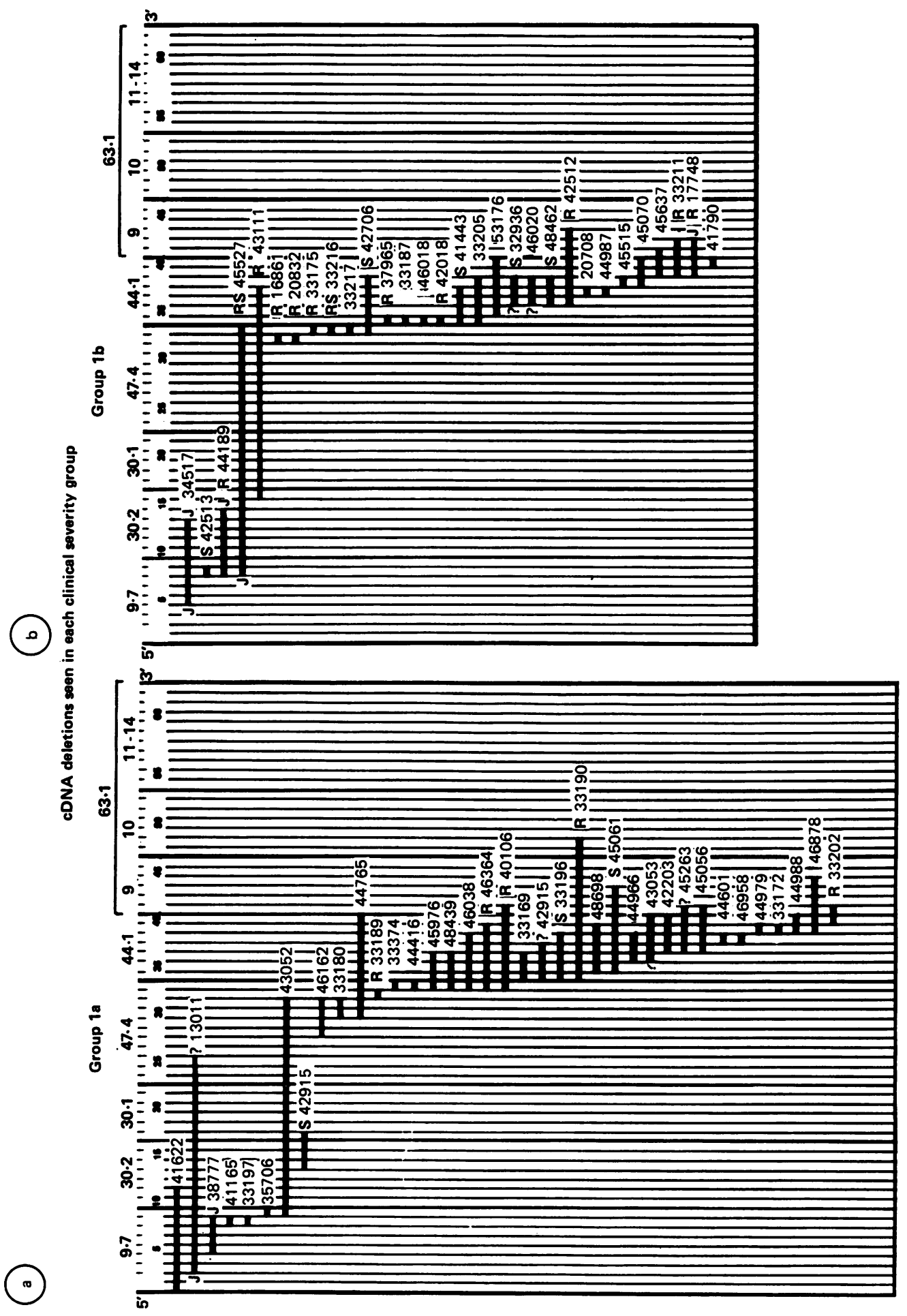




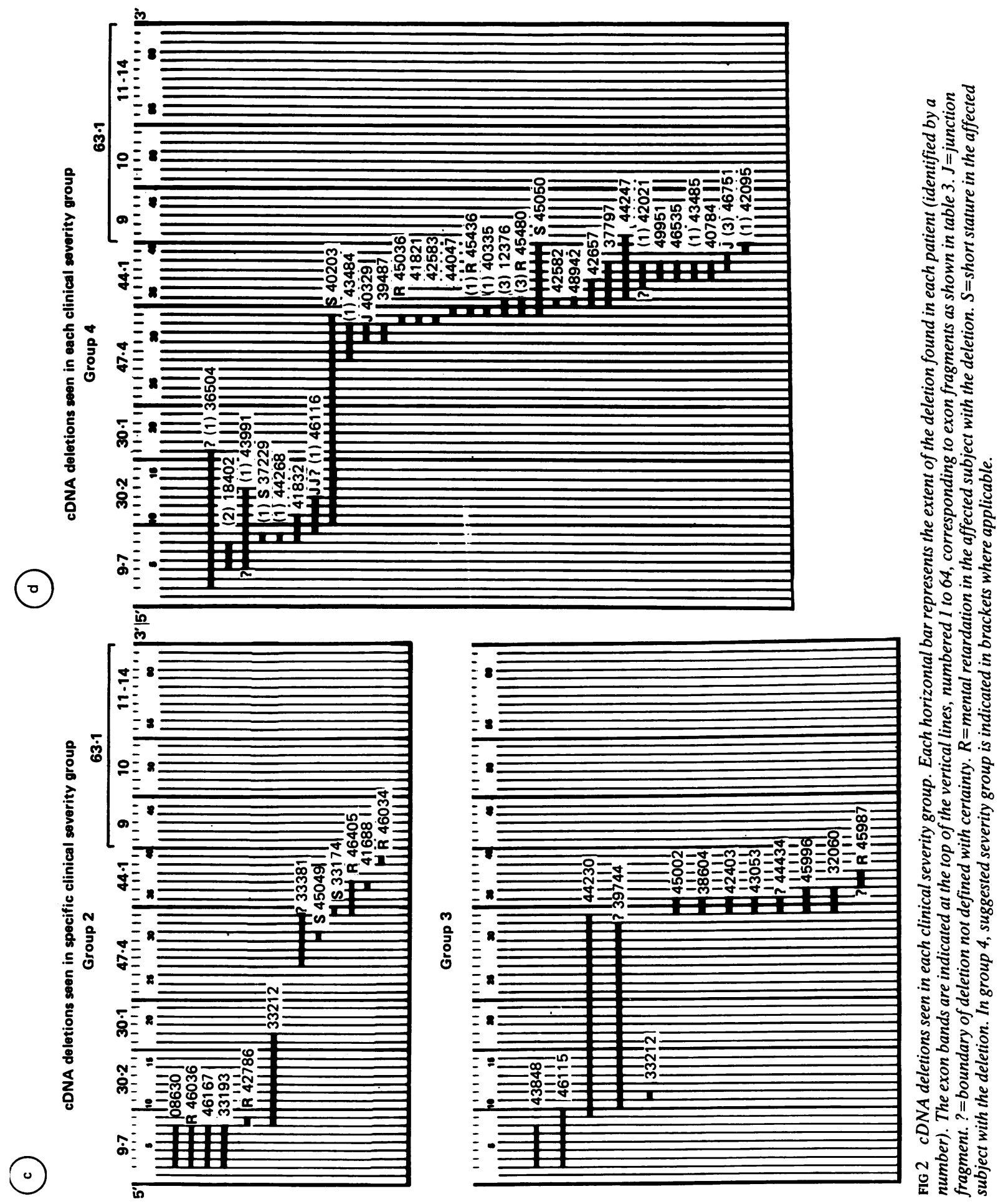




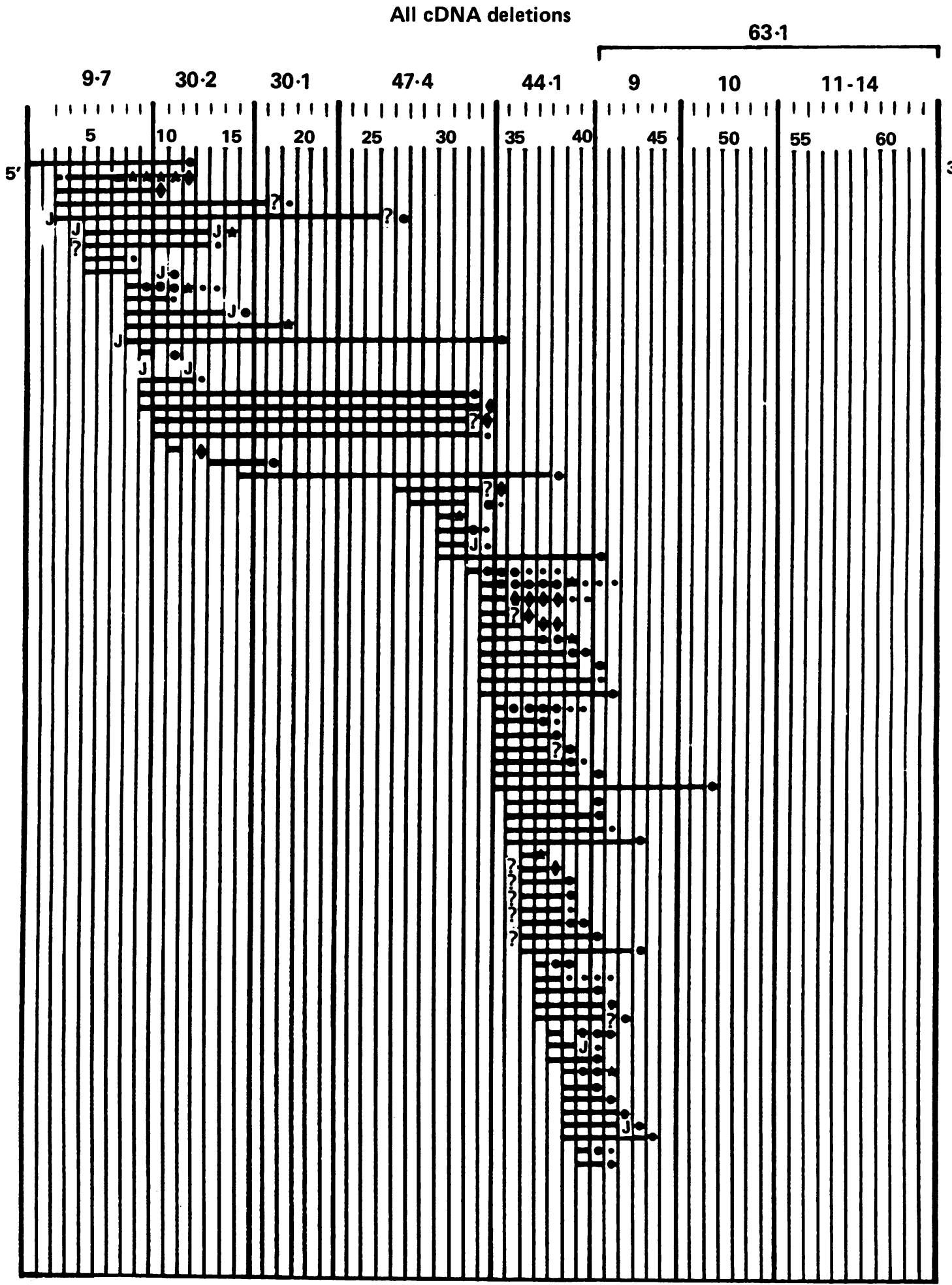

FIG 3 All cDNA deletions. Each separate deletion defined in this survey is represented by a horizontal bar. Some deletions were found in one subject only, but others were found in more than one. The symbols indicate the clinical group of the subject with that deletion, and where more than one subject had the deletion, each one is represented by one symbol, shown next to the relevant horizontal bar; the number of symbols thus indicates the number of boys shown to have the deletion. 
TABLE 4 Clinical severity and frequency of cases occurring with shared deletions.

\begin{tabular}{|c|c|c|c|c|c|}
\hline \multirow{2}{*}{$\begin{array}{l}\text { Deletion } \\
\text { type }\end{array}$} & \multicolumn{5}{|c|}{ Clinical severity (by group) } \\
\hline & $\begin{array}{l}\text { Group } 1 \\
a\end{array}$ & $b$ & Group 2 & Group 3. & $\begin{array}{l}\text { Group } 4 \\
\text { [estimated severity } \\
\text { in brackets] }\end{array}$ \\
\hline $3-7$ & & & $4(R, N, N)$ & $1(\mathrm{~N})$ & \\
\hline 8 & $2(\mathrm{~N}, \mathrm{~N})$ & $1(\mathrm{~S})$ & $1(\mathbf{R})$ & & $2(\mathrm{SN}, \mathrm{N}) \quad[2 \mathrm{gp} 1]$ \\
\hline $28-31$ & $1(\mathrm{~S})$ & & & & $1 \quad[g p 1]$ \\
\hline $30-31$ & 1 & & & & 1 \\
\hline 32 & $1(\mathrm{R})$ & $2(\mathrm{R}, \mathrm{R})$ & & & $3(\mathrm{R}, \mathrm{N})$ \\
\hline 33 & $2(\mathrm{~N}, \mathrm{~N})$ & 3 (R. R. S) & $1(\mathrm{~S})$ & & $3(\mathrm{R}, \mathrm{N})$ \\
\hline $33-34$ & & & & $4(\mathrm{~N}, \mathrm{~N}, \mathrm{~N})$ & $2(\mathrm{R}) \quad[1 \mathrm{gp} 3]$ \\
\hline $33-35$ & & & & $2(\mathrm{~N})$ & \\
\hline $33-36$ & $2(\mathrm{~N})$ & & $1(\mathrm{R})$ & & \\
\hline $33-38$ & $1(\mathrm{~N})$ & $1(\mathrm{~S})$ & & & \\
\hline 34 & & $4(\mathrm{R}, \mathrm{N}, \mathrm{R}, \mathrm{R})$ & & & 2 \\
\hline $34-36$ & $1(\mathrm{~N})$ & & & & 1 \\
\hline $34-38$ & & $1(\mathrm{~N})$ & & & 1 \\
\hline $36-38$ & 1 & $1(\mathrm{~S})$ & & & \\
\hline 37 & & $2(\mathrm{~N})$ & & & \\
\hline $37-38$ & & & & & $4(N, N, N)[1$ gp 1] \\
\hline 38 & $2(\mathrm{~N}, \mathrm{~N})$ & $1(\mathrm{~N})$ & & & \\
\hline 39 & $2(\mathrm{~N}, \mathrm{~N})$ & & $1(\mathrm{R})$ & & \\
\hline 40 & & $1(\mathrm{~N})$ & & & {$\left[\begin{array}{lll}1 & g p & 1\end{array}\right]$} \\
\hline
\end{tabular}

phenotype (table 4). In some cases, however, the same deletion was found in boys with severe (group 1) and intermediate (group 2) phenotypes.

The hypothesis that DMD results from a frameshift deletion, and that BMD results from an in frame deletion, is supported by some of our data. Several examples were found in which deletions differing by one exon containing fragment were associated with disease of mild phenotype in one case and severe in another. This suggested that the deletion of a specific exon containing fragment had altered the translational reading frame. For example, deletion of exon fragment 33 occurred in boys with DMD, but deletion 33-34, longer by the inclusion of exon band 34 , occurred in boys with BMD. Conversely, a deletion of exon fragments 33-35 was found in two boys with BMD, but the addition of deletion of fragment 36 to this was associated with DMD, suggesting that a deletion of fragment 36 alone renders the translational reading frame out of phase. Disease of intermediate type in a boy who lost ambulation at 13 years of age was found in a patient with a deletion of fragment 36 only. Similarly, deletion of exon bands 9-31 gave a DMD phenotype (fig 3), while deletion of exon bands 9-32 gave a BMD phenotype. This would suggest that exon band 32 contains a frameshift exon (or exons) to bring the BMD case back in frame. This is substantiated by the demonstration that deletion of exon band 32 alone produced a DMD phenotype in three cases.
Deletion of exon bands 33 with 34 gave rise to BMD, and inclusion of the next exon band (35) in the deletion still caused a BMD phenotype. Smaller deletions within these $\mathrm{BMD}$ deletions gave rise to DMD; for example, exon band 33 only or exon band 34 only, suggesting that these smaller deletions each bring the reading frame out of phase, but when deleted together they result in an in frame message.

The finding of the same deletion (3-7) in five boys, four of whom have the intermediate phenotype (group 2) and one of whom has BMD, strongly suggests that this particular deletion is associated with disease of intermediate or mild severity. ${ }^{21} 33$ Seven of our patients (Nos 46036, 33193, 08630, 42786, 18402, 41165, and 37229) with deletions within the first 10 exons of the DMD/BMD gene were included in the paper by Malhotra et al. ${ }^{21}$ Four further cases from other centres show 3-7 exon deletions in association with a BMD or intermediate phenotype, despite the fact that exon/codon border analysis suggests that this deletion would cause a translational frameshift. ${ }^{21}$

Four domains of dystrophin have been postulated, based on the predicted amino acid sequence. ${ }^{16}$ The $5^{\prime}$ end (exons 3 to 9 ) is homologous with the actin binding domain of $\alpha$ actinin $^{37}$; a long triple helical repeat segment is then found before a cystein rich domain and the $c^{\prime}$ terminal domain. Large deletions of the helical segment may be possible without much reduction in function of the protein product. This is borne out by the observation that a long $10-31$ 
deletion was found in BMD patient 39744 and deletion 9-32 in BMD patient 44230. Deletion 3-7 occurs within the actin binding homologous region.

Deletions in patients with the milder phenotypes are more homogeneous than the DMD deletions in this series. Of the 25 deletions found in phenotypic groups 2 and 3, five delete exons 3-7, five delete exons 33-34, and two delete exons 33-35. Thus only 13 in this group are unique deletions, and of the 13 BMD deletions only five are unique. Read $e t a^{19}$ also reported a high proportion of 33-34 (seven cases) and 33-35 (three cases) deletions in 14 BMD patients.

Some deletions are found in patients with both the intermediate and the severe phenotype. Patients from groups 1 and 2 share the same deletion for exons $8,33,33-36$, and 39 , suggesting that this degree of variation in phenotype can result from non-allelic variation, related either to genetic background or to environmental factors. In dystrophic dogs with no demonstrable dystrophin, the severity of their disease varies between litters even when they are presumed (by descent from the same affected male) to carry the same mutation. ${ }^{38}$

As previously suggested, ${ }^{139-41}$ we found that the degree of mental retardation in muscular dystrophy was related to the severity of the disorder. It occurred in $34 \%$ of DMD patients, in $40 \%$ of those in group 2 , and in $9 \%$ of boys with BMD. Severe retardation was not found in boys in groups 2 and 3 , but occurred in $18 \%$ of those in group 1 (table 1 ). Delayed speech occurred in $74 \%$ of boys in group 1 , and $100 \%$ of boys in group 2 , but also in $67 \%$ of boys in group 3 (table 1). It is doubtful whether this data on delayed speech, depending on a retrospective history from the parents, is of any discriminative value.

The distribution of deletions in boys with mental retardation was similar to that seen in all patients and showed no unique abnormalities. Three deletion types are represented by more than one patient with mental retardation (table 4; these are deletions 32 , 33 , and 34), but patients without mental retardation are also found to have these deletions.

Despite the suggestion that short stature with growth hormone insufficiency may be associated with amelioration of the progression of DMD, ${ }^{42}$ it appears from our survey that short stature is found more commonly in boys with severe DMD; $19 \%$ of boys in group 1 and $17 \%$ of those in group 2, but none of the boys in group 3, were at or below the 3rd centile for height. Short stature may therefore be one of the manifestations of the disease itself. ${ }^{43}$

Affected boys with short stature were found to have deletions throughout the deletion spectrum, and boys with and without short stature share deletions 8, 28-31, 33, 33-38, and 36-38 (table 4). It appears, therefore, that short stature and mental retardation are not the result of specific deletion mutations of the DMD gene.

It is hoped that studies correlating the molecular abnormalities of dystrophin with the deletion data in these patients will lead to further understanding of the pathogenetic mechanisms involved in Duchenne and Becker muscular dystrophy.

We gratefully acknowledge the support of The Muscular Dystrophy Group of Great Britain and Northern Ireland and The Spastics Society. We also acknowledge the assistance of Miss Elizabeth Manners in the preparation of this manuscript.

\section{References}

${ }^{1}$ Dubowitz V. Mental retardation in Duchenne muscular dystrophy. In: Pathogenesis of human muscular dystrophies. Excerpta Medica international congress series 404. Amsterdam: Excerpta Medica, 1976:689-94.

${ }^{2}$ Emery AEH. In: Duchenne muscular dystrophy. Oxford monographs in medical genetics No 15. Oxford: Oxford University Press, 1987:99-102.

${ }^{3}$ Emery AEH, Skinner R. Clinical studies in benign (Becker type) X-linked muscular dystrophy. Clin Genet 1976;10:189-201.

4 Davies KE, Pearson PL, Harper PS, et al. Linkage analysis of two cloned DNA sequences flanking the DMD locus on the short arm of the human $\mathrm{X}$ chromosome. Nucleic Acids Res 1983;11:2303-12.

5 Kingston HM, Sarfarazi M, Thomas NST, Harper PS. Localisation of the BMD gene on the short arm of the X chromosome by linkage to cloned DNA sequences. Hum Genet 1984;67:6-17.

6 Kunkel LM, Monaco AP, Middlesworth W, Ochs HD, Latt SA. Specific cloning of DNA fragments absent from the DNA of a male patient with an X chromosome deletion. Proc Natl Acad Sci USA 1985;82:4778-82.

${ }^{7}$ Ray PN, Belfall B, Duff C, et al. Cloning of the breakpoint of an $X ; 21$ translocation associated with Duchenne muscular dystrophy. Nature 1985;318:672-5.

${ }^{8}$ Kunkel LM, Hejtmancik JF, Caskey. CT, et al. Analysis of deletions in DNA from patients with Becker and Duchenne muscular dystrophy. Nature 1986;322:73-7.

9 Hart KA, Hodgson S, Walker A, et al. DNA deletions in mild and severe Becker muscular dystrophy. Hum Genet 1987;75: 281-5.

10 Monaco AP, Neve RL, Colletti-Feener C, Bertelson CJ, Kurnit DM, Kunkel LM. Isolation of candidate cDNA for portions of the DMD gene. Nature 1986;323:646-50.

1 Burghes AHM, Logan C, Hu X, Belfall B, Worton RG, Ray PN. A cDNA clone from the D/BMD gene. Nature 1987;328: 434-7.

12 Forrest SM, Cross GS, Speer A, Gardner-Medwin D, Burn J, Davies KE. Preferential deletion of exons in Duchenne and Becker muscular dystrophies. Nature 1987;329:638-40.

${ }^{13}$ Koenig M, Hoffman EP, Bertelson CJ, Monaco AP, Feener C, Kunkel LM. Complete cloning of the Duchenne muscular dystrophy (DMD) cDNA and preliminary genomic organization of the DMD gene in normal and affected individuals. Cell 1987;50:509-17.

${ }^{14}$ Smith TJ, Forrest SM, Cross GS, Davies KE. Duchenne and Becker muscular dystrophy mutations: analysis using $2.6 \mathrm{~kb}$ of muscle cDNA from the $5^{\prime}$ end of the gene. Nucleic Acids Res 1987;15:9761-9. 
${ }^{15}$ Forrest SM, Cross GS, Flint T, Speer A, Robson KJH, Davies $\mathrm{KE}$. Further studies of gene deletions that cause Duchenne and Becker muscular dystrophy. Genomics 1988;2:109-14.

${ }^{16}$ Koenig M, Monaco AP, Kunkel LM. The complete sequence of dystrophin predicts a rod-shaped cytoskeletal protein. Cell 1988;53:219-28.

17 Monaco AP, Bertelson CJ, Liechti-Gallati S, Moser H, Kunkel LM. An explanation for the phenotypic differences between patients bearing partial deletions of the DMD locus. Genomics 1988;2:90-5.

${ }^{18}$ Brown RH, Hoffman EP. Molecular biology of Duchenne muscular dystrophy. Trends Genet 1988;11:480-4.

19 Read AP, Mountford RC, Forrest SM, Kenwrick SJ, Davies $\mathrm{KE}$, Harris R. Patterns of exon deletions in Duchenne and Becker muscular dystrophy.' Hum Genet 1988;80:152-6.

20) Hoffman EP, rischbeck KH, Brown RH, et al. Characterisation of dystrophin in muscle biopsy specimens from patients with Duchenne's or Becker's muscular dystrophy. $N$ Engl J Med 1988:318: $1363-8$.

21 Malhotra SB, Hart KA, Klamut HJ, et al. Frame-shift deletions in patients with Duchenne and Becker muscular dystrophy. Science 1988;242:755-9.

${ }^{22}$ Nudel U, Robzyk K, Yaffe D. Expression of the putative Duchenne muscular dystrophy gene in differentiated myogenic cell cultures and in the brain. Nature 1988;331:635-8.

${ }^{23}$ Nudel I, Zuk D, Einat P, et al. Duchenne muscular dystrophy gene product is not identical in muscle and brain. Nature 1989;337:76-8.

24 Dubowitz V. In: Muscle disorders in childhood. Major problems in clinical paediatrics Vol XVL. Philadelphia: Saunders, 1978: $31-6$.

${ }^{25}$ Heckmatt JZ, Dubowitz VG, Hyde SA, Florence J, Gabain AC, Thompson N. Prolongation of walking in DMD with lightweight orthoses: review of 57 cases. Dev Med Child Neurol 1985;27: $149-54$.

26 Illingworth RS. The development of the infant and young child-normal and abnormal. 5th ed. Edinburgh: Churchill Livingstone, 1974:153-4.

27 Kunkel LM, Smith KD, Boyer SH, et al. Analysis of human Ychromosome-specific reiterated DNA in chromosome variants. Proc Natl Acad Sci USA 1977,74:1245-9.

${ }^{28}$ Maniatis T, Fritsch CF, Sanbrook J, eds. Molecular cloning: $a$ laboratory manual. Cold Spring Harbor, New York: Cold Spring Harbor Laboratories, 1982.

${ }^{29}$ Feinberg AP, Vogelstein B. A technique for radiolabelling DNA restriction endonuclease fragments to high specific activity. Anal Biochem 1983;132:6-13.

30 Burghes AHM, Duff C, Hart KA, et al. Exons deleted and duplicated in Becker and Duchenne muscular dystrophy at the 5 ' end of the DMD gene. (In preparation).

31 Wapenaar MC, Kievits T, Hart KA, et al. A deletion hot spot in the Duchenne muscular dystrophy gene. Genomics 1988;2: 101-8.

${ }^{32}$ Hart KA, Abbs S, Wapenaar MC, Cole CG, Hodgson SV, Bobrow M. Molecular deletions in the Duchenne/Becker muscular dystrophy gene. Clin Genet 1989;35:251-60.

${ }^{33}$ Hart KA. Molecular deletions in the Duchenne/Becker muscular dystrophy locus. PhD thesis, University of London, 1989.

${ }^{34}$ Brooke MH, Fenichel GM, Griggs RC, et al. Clinical investigation in Duchenne dystrophy. 2. Determination of the power of therapeutic trials based on the natural history. Muscle Nerve 1983; February:91-103.

${ }^{35}$ Hyser CL, Province M, Griggs RC, et al. Genetic heterogeneity in Duchenne dystrophy. Ann Neurol 1987;22:411-20.

${ }^{36}$ Darras BT, Blattner P, Harper JF, Spiro AJ, Alter S, Francke $\mathrm{U}$. Intragenic deletions in 21 Duchenne muscular dystrophy (DMD)/Becker muscular dystrophy (BMD) families studied with the dystrophin cDNA: location of breakpoints on HindIII and $B g / I I$ exon-containing fragment maps, meiotic and mitotic origin of the mutations. Am J Hum Genet 1988;43:620-9.

${ }^{37}$ Hammonds RG. Protein sequence of DMD is related to actinbinding domain of $\alpha$-actinin. Cell 1988;51:1.

38 Cooper BJ, Winand NJ, Stedman $\mathrm{H}$, et al. The homologue of the Duchenne locus is defective in X-linked muscular dystrophy of dogs. Nature 1988;334:154-6.

${ }^{39}$ Prosser EJ, Murphy EG, Thompson MW. Intelligence and the gene for Duchenne muscular dystrophy. Arch Dis Child 1969;44:221-30.

40 Miller G, Tunnecliffe M, Douglas PS. IQ, prognosis, and Duchenne muscular dystrophy. Brain Dev 1985;7:7-9.

${ }^{41}$ Rabbi-Bortolini E, Zatz M. Investigations on genetic heterogeneity in Duchenne muscular dystrophy. Am J Med Genet 1986;24:111-7.

42 Zatz M, Betti RTB, Levy J. Benign Duchenne muscular dystrophy in a patient with growth hormone deficiency. Am J Med Genet 1981;10:301-4.

${ }^{43}$ Eiholzer U, Boltshauser E, Frey D, Molinari L, Zachmann M. Short stature: a common feature in Duchenne muscular dystrophy. Eur J Pediatr 1988;147:602-5.

Correspondence to Professor M Bobrow, Paediatric Research Unit, United Medical and Dental Schools of Guy's and St Thomas's Hospitals, Guy's Campus, London SE1 9RT. 